\title{
TRANSGENE IDENTITY AND NUMBER OF INTEGRATION SITES AND THEIR CORRELATION WITH RESISTANCE TO PSTV IN TRANSGENIC PEANUTS CARRYING PEANUT STRIPE VIRUS (PStV) COAT PROTEIN GENE
}

\author{
Dwi Hapsoro ${ }^{1}$, Hajrial Aswidinnoor ${ }^{1}$, Rusmilah Suseno ${ }^{2}$, Jumanto $^{3}$, and Sudarsono ${ }^{1}$
}

\begin{abstract}
Transgene Identity and Number of Integration Sites and Their Correlation with Resistance To PStV in Transgenic Peanuts Carrying Peanut Stripe Virus (PStV) Coat Protein Gene. This research aimed to determine (1) the identity and copy number of PStV $c p$ gene in transgenic peanut plants carrying PStV $c p$ gene and (2) correlation between the identity and the number of integration sites and resistance to PStV infection. One $T_{0}$ transgenic peanut was selfed up to five generations. $T_{2}, T_{3}$, and $T_{5}$ plants were mechanically inoculated with PStV. Samples of $T_{5}$ plants derived from several different $\mathrm{T}_{4}$ plants were subjected to Southern analysis to confirm the integration of PStV $c p$ gene and to determine its identity and copy number. The Southern analysis showed three bands of different size, i.e. $1.1 \mathrm{~kb}, 1.3 \mathrm{~kb}$, and $5.8 \mathrm{~kb}$. Most of the lines of $\mathrm{T}_{5}$ generation have one insertion site, suggesting that the three insertion sites were located in different loci. Based on the phenotypic data, the transgenes of $1.1 \mathrm{~kb}$ and $1.3 \mathrm{~kb}$ were functional, resulting in resistant or recovery phenotype, while that of $5.8 \mathrm{~kb}$ was not functional. Copy number apparently had no effects on the phenotypes.
\end{abstract}

Key words: copy number, Peanut Stripe Virus (PStV), resistance, transgene identity transgenic peanut

\section{INTRODUCTION}

Integration sites and copy number of transgenes has been reported to influence their expression. Different independent transformants containing one copy number of transgene show different expression level; some show no expression. This phenomenon is called positional effects (Meyer, 1995; Matzke \& Matzke, 1995), meaning that integration sites of a transgene in genome affect its expression. It has been documented that a transgene of more than one copy was not expressed, or silenced, while that of only one copy was expressed, or not silenced.

Studies on silencing of transgene of more than one copy led to the finding of a phenomenon called homology-dependent gene silencing, i.e. genes are silenced because they share the same nucleotide sequence (Smith et al, 1994; Meyer, 1995; Mueller et al.,1995; Matzke \& Matzke, 1995a, 1995b; English et al., 1996; Prins et al., 1996; Meyer \& Saedler 1996; Fagard \& Vaucheret, 2000; Vance \& Vaucheret, 2001; Mlotshwa et al., 2002). DNA-DNA, DNARNA, and RNA-RNA sequence homology has been reported to cause gene silencing (Meyer, 1995; Matzke \& Matzke, 1995; Baulcombe, 1996). It has been documented that there are two types of gene silencing: transcriptional gene silencing (TGS) and post-transcriptional gene silencing (PTGS). TGS occurs due to inhibition of transcription while PTGS occurs after transcription, that is, the transcript (mRNA) is degraded.

Transgenic plants containing a viral gene could exhibit resistance to the virus. The resistance is believed to be through PTGS developed by sequence homology between viral RNA and transgene RNA. PTGS results in degradation of transgene RNA as well as viral RNA so that the virus cannot develop in plant cells. This phenomenon refers to homology-dependent virus resistance, one form of homology-dependent gene silencing.

We previously reported three kinds of response of transgenic peanuts to PStV infection (Hapsoro et al., 2005; Hapsoro, 2005), i.e. resistant, recovery, and susceptible. Resistant plants were those that showed no symptoms of PStV infection. Recovery plants were those that showed chlorotic ring mottle on one or more leaves and no symptoms on newly emerging leaves. Susceptible plants were those that showed severe blotch symptom on one leaf and all newly emerging leaves.

Resistant and recovery response is expected to result from $\mathrm{PStV} c p$ transgene being located in functional loci, while susceptible response is expected to be due to the transgene being located in nonfunctional loci. However, identity and copy number of the transgene has not been identified yet. Goodwin

\footnotetext{
${ }^{1}$ Lecturer at Departemen of Agronomy, Faculty of Agriculture, University of Lampung, e-mail: hapsorodwi@ yahoo.com

${ }^{2}$ Lecturer at Departemen of Plant Protection, Bogor Agricultural University

${ }^{3}$ Researcher at BB Biogen, Bogor
} 
et al. (1996) reported that transgenic tobacco plants containing two or more copies of TEV (tobacco etch virus) $c p$ transgene showed resistant response to TEV, while those containing one copy of the transgene exhibited recovery response.

This research aimed to determine identity and copy number of PStV $c p$ transgene in transgenic peanuts cv.Gajah and their correlation to resistance against PStV.

\section{MATERIALS AND METHODS}

Plant Materials. This experiment used transgenic peanuts cv.Gajah containing PStV cp gene as previously reported (Hapsoro, 2005). These plants resulted from transformation using particle inflow gun (Higgins \& Dietzgen, 2000). One regenerant derived from one transformation event was clonally propagated in vitro through axillary branching. T0 plants were grown to maturity in plastichouse. $\mathrm{T}_{0: 1}$ seeds were sown to get $\mathrm{T} 1$ plants that were grown to produce $\mathrm{T}_{1: 2}$ seeds. $\mathrm{T}_{1: 2}$ seeds were sown to get $\mathrm{T} 2$ plants that were grown to produce $\mathrm{T}_{2: 3}$ seeds. Such selfings were conducted until five generations and in so doing T5 plants were obtained.

Nomenclature of plants employed in this experiment is as follows. T0 plants were designated as G. $T_{1}, T_{2}, T_{3}, T_{4}$, and $T_{5}$ plants were designated as $G$ (n), G(n.o), G(n.o.p), G(n.o.p.q), G(n.o.p.q.r), G(n.o.p.q.r) respectively, where $n, o, p, q$, and $r$ are cardinal numbers, respectively. As an ilustration, $\mathrm{G}$ (1) is a T1 plant number $1, \mathrm{G}(2)$ is a T1 plant number $2, \mathrm{G}(3)$ is a T1 plant number 3 , and so on. $\mathrm{G}(1.1)$ is a T2 plant number 1 derived from G (1). G (1.2) is a T2 plant number 2 derived from $G(1)$. G (2.1) is a T2 plant number 1 derived from $G$ (2). Arbitrarily, G (8.10.8.4.1) is a T5 plant number 1 derived from a T4 plant G (8.10.8.4).

All plants were grown in an insect-proof plastichouse. Plants were grown in polybags $(45 \mathrm{~cm} \mathrm{x}$ $50 \mathrm{~cm})$ containing a mixture of soil and sand $(2: 1)$. Watering was done to field capacity. Pest control was carried out using Confidor and Kelthene, while disease control was conducted using Dithane 45.

PStV inoculation. $\mathrm{T}_{0}, \mathrm{~T}_{2}, \mathrm{~T}_{3}, \quad$ and $\mathrm{T}_{5}$ was mechanically inoculated with PStV at least three times, i.e. at 2, 4 and 6 weeks after planting. Further inoculation every two weeks were done on plants that did not show disease symptom to ensure that the plants were really resistant. PStV inoculation was also conducted on non-transgenic peanuts cv.Gajah as a control.

Inoculum of PStV was maintained and propagated in peanut plants cv. Kelinci which had been inoculated with PStV isolate Bogor that caused severe blotch-stripe symptom in peanut plants cv. Landak (Akin,1998; Avivi, 2000; Yasin, 2001). The fully- open-youngest leaves were spread with carborundum powder (600 mess) and rubbed with cutton bud previously dipped in inoculum solution. The inoculum was prepared by grinding PStVinfected leaves $(0.5 \mathrm{~cm}$ in diameter $)$ in $200 \mu \mathrm{l}$ of phosphate buffer solution $\mathrm{pH} 7$. Effectiveness of the inoculation was evaluated using an indicator plant, i.e Chenopodium amaranticolor.

DNA Extraction. Total nucleic acid was extracted using CTAB method (Murray and Thompson 1980). Four or five leaves were frozen in liquid nitrogen and ground to powder using pestle and mortar. The powdered leaves were added with 3-4 ml of extraction buffer of $65^{\circ} \mathrm{C}$, shaken slowly, and the suspension was incubated for 1 hour in a water bath at $65^{\circ} \mathrm{C}$. The suspension was added with the same volume of chloroform and isoamylalcohol mix (24:1), slowly shaken, and centrifuged at 10,000 rpm at room temperature for 30 minutes. The liquid face on the upper part was pipetted and put into a new tube, added with 0.6 volume of isopropanol and 0.1 volume of sodium acetate $5 \mathrm{M}$, incubated for 10 minutes, and centrifuged at $10,000 \mathrm{rpm}$ at room temperature for 30 minutes. The supernatant was removed and the pellet was resuspended with alcohol $70 \%$, centrifuged at $8,000 \mathrm{rpm}$ at room temperature for 20 minutes. The pellet was solubilized in $500 \mu \mathrm{l}$ of aquadest and DNA concentration in the solution was measured using spectrophotometer at $260 \mathrm{~nm}$. 2-5 $\mu \mathrm{l}$ of DNA samples were run in gel electrophoresis with agarose $1 \%$ to check the quality of the DNA.

Southern Analysis. Southern analysis was conducted according to Higgins and Dietzgen (2000). 10-20 $\mu \mathrm{g}$ of DNA in 150-300 $\mu \mathrm{l}$ of aquadest was digested overnight with $\mathrm{NcoI}$ at $37^{\circ} \mathrm{C}$. The solution was added with 2.5 volume of ethanol $100 \%$ and 0.1 volume of sodium acetate $5 \mathrm{M}$ and incubated at $-20^{\circ} \mathrm{C}$ for 2 hours. The mixfure was centrifuged at $13,000 \mathrm{rpm}$ and at $4^{\circ} \mathrm{C}$ for 30 minutes. The DNA pellet was washed by adding with ethanol and spinning at 13,000 
rpm for 10 minutes. The DNA was solubilized in 50 $\mu \mathrm{l}$ sterile aquadest.

The DNA solution was electrophoresed in agarose $1 \%$ at 80 volt for 3 hours. The agarose gel was shaken in denaturing solution for $2 \times 20$ minutes and in neutralization solution for $2 \times 20$ minutes. The DNA was transferred to positively charged nylon membrane using capillary method overnight. Hybridization reaction was done using a radioactive probe and the result was visualized.

\section{RESULTS AND DISCUSSION}

T5 plants showed five different responses to PStV infection, i.e. resistant, quick recovery, slow recovery, less susceptible and susceptible. Resistant plants (score 0) were those that showed no symptoms of disease caused by PStV. Quick recovery plants (score 1) were those that showed chlorotic ring mottle symptoms on 1-3 leaves and no symptoms on newly emerging leaves. Slow recovery (score 2) plants were those that showed chlorotic ring mottle symptoms on at least 4 leaves and no symptoms on newly emerging leaves. Less susceptible (score 3) plants were those that showed chlorotic ring mottle symptoms on one leaf and all newly emerging leaves. Susceptible plants (score 4) were those that showed severe blotch symptoms on one leaf and all newly emerging leaves (Figure 1).

The result of Southern analysis was presented in Table 1 and its autoradiogram was presented in Figure 2. It showed that there were three integration sites,
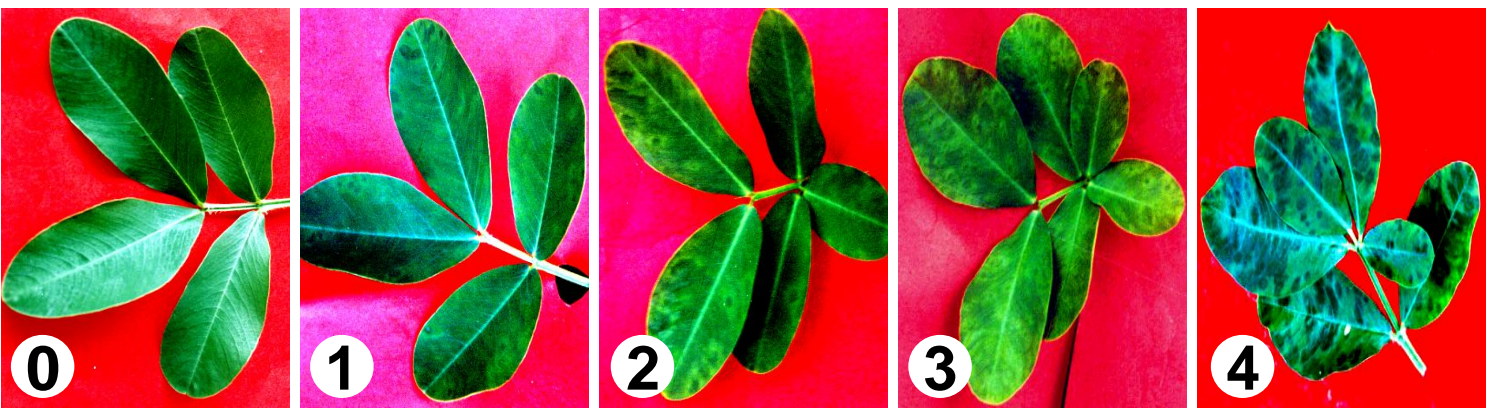

Figure 1. Symptoms as a response to PStV inoculation on leaves of peanut plants transformed with coat protein gene of peanut stripe virus (PStV CP gene). Numbers on the left side of each picture are scores of symptom, which indicate degree of severity. Score $0=$ resistant; plants did not show disease symptoms. Score 1 = quick recovery; plants showed symptoms of chlorotic ring mottle on at least 1-3 leaves and no symptoms on newly emerging leaves. Score 2 = slow recovery; plants showed symptoms of chlorotic ring mottle symptoms on at least 4 leaves and no symptoms on newly emerging leaves. Score 3 = less susceptible; plants showed symptoms of chlorotic ring mottle on one leaf and on all newly emerging leaves. Score $4=$ susceptible. Plants showed severe blotch systemic symptoms on their leaves.

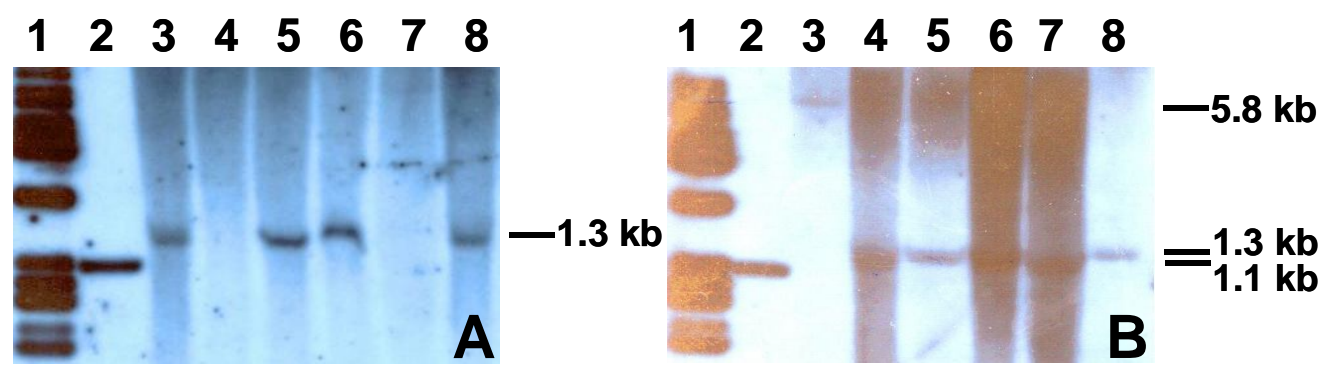

Figure 2. Results of Southern analysis of T5 transgenic peanut plants. . A: $1=1$-kb ladder, $2=$ positive control, $3=\mathrm{G}(18.2 .2 .1 .1), 4=\mathrm{G}(1.5 .2 .1 .2), 5=\mathrm{G}(8.14 .4 .1), 6=\mathrm{G}(9.4 .16 .1 .3), 7=\mathrm{G}(17.1 .8 .1 .1)$, and $8=$ (6.1.3.1.3). B: $1=1-\mathrm{kb}$ ladder, $2=$ positive control, $3=\mathrm{G}(1.5 .2 .1 .1), 4=\mathrm{G}(8.4 .3 .1 .3), 5=\mathrm{G}$ (8.11.6.1.3), $6=\mathrm{G}$ (9.4.16.1.2), 7 = G9CP3 (16.4.1.1.2), and $8=$ G9CP3 (18.1.5.1.2). 
which were represented by bands of $5,8 \mathrm{~kb}, 1,3 \mathrm{~kb}$, and $1.1 \mathrm{~kb}$ (Figure 2). Of 49 lines tested, 24 lines had only 1,1-kb band, 17 lines had only 1,3-kb band, 4 lines had only 5,8-kb band, 2 lines had 1.3-kb and 5.8$\mathrm{kb}$ bands, and 2 lines had no bands. Thus, of 49 lines evaluated, 45 lines (92\%) showed only one band (Table 1).

$\mathrm{T} 5$ progenies of each T4 plant were divided into two portions. Some were inoculated with PStV to get the response to PStV and the rest were subjected to Southern analysis to confirm transgene integration (Table 1). In this case, because T5 plants that were subjected to Southern analysis were not PStVinoculated, we did not know directly phenotype of the T5 plants with certain transgene identity. However, the phenotype could be suggested by comparing the response data and the Southern analysis data (Table 1). If the Southern data shows segregation, the response data should also show segregation because the two data were derived from the T5 progenies of one T4 plant. If the Southern data shows bands of a particular size, the response data should show plants that are resistant, recovery, susceptible. In this way, we could suggest that bands of a particular size cause certain phenotypes. However, we cannot rule out the possibility that certain bands do not cause resistance because particular transgene integration sites might not be functional.

The response data of $\mathrm{T} 5$ progenies of the $\mathrm{T} 4$ plants $G(8.10 .8 .4)$ and $G(8.10 .8 .6)$ showed that all of the T5 plants were resistant and the Southern data showed that all of the T5 plants showed only $1.1 \mathrm{~kb}$ band, suggesting that the transgene identity of $1.1 \mathrm{~kb}$ band causes resistance. This suggestion was supported by the results reported by Hapsoro et al (2005) that all of $\mathrm{T} 6$ progenies of the T5 plant $\mathrm{G}$ (8.10.8.4.1) were resistant to $\mathrm{PStV}$ and that all of the $\mathrm{T} 7$ progenies of the T6 plants $\mathrm{G}$ (8.10.8.4.1.1), $\mathrm{G}$ (8.10.8.4.1.2), and $\mathrm{G}$ (8.10.8.4.1.3) were also resistant. This suggestion was also supported by comparing the response data and the Southern data of $\mathrm{T} 5$ progenies of the $\mathrm{T} 4$ plants $\mathrm{G}$ (6.2.4.1) and $G$ (6.4.14.2). Even though the response data showed that some T5 plants were susceptible, the other resistant T5 plants should result from the transgene identity of of $1.1 \mathrm{~kb}$ band (Table 1 ).

The response data of T5 progenies of T4 plants G9 (9.4.16.1) and G9 (16.4.19.1) showed that all of the progenies were resistant and their Southern data showed two bands of $1.1 \mathrm{~kb}$ and $1.3 \mathrm{~kb}$ in size. These data suggest that the transgene identity of $1.1 \mathrm{~kb}$ and $1.3 \mathrm{~kb}$ give rise to resistance. However, comparing the response data and the Southern data of T5 progenies of T4 plants G9 (8.14.4.1) and G9 (18.2.2.1) ends up with different conclusion. The response data showed the T5 progenies were resistant and recovery plants and the Southern data showed only one band, i.e $1.3 \mathrm{~kb}$, suggesting that the transgene identity of $1.3 \mathrm{~kb}$ might result in resistance or recovery. Using the same method by looking at the response data and the Southern data of T5 progenies of T4 plant G9 (9.2.5.1), we come up with the suggestion that the transgene identity of $1.1 \mathrm{~kb}$ or 1.3 $\mathrm{kb}$ led to resistance or recovery.

Based on the comparison of Southern data and phenotypic data as previously stated, it is plausible to conclude that the transgene identity of $1.1 \mathrm{~kb}$ and 1.3 $\mathrm{kb}$ might cause either resistance or recovery. This data was supported by phenotypic data of T4 plant G9 (9.2.5.1.2) and its progenies. A T5 plant G9 (9.2.5.1.2), which was based on previous analysis should have transgen $1.1 \mathrm{~kb}$ or $1.3 \mathrm{~kb}$, was in fact a recovery plant but produce only resistant T6 progenies (Hapsoro et al., 2005). Likewise, a T5 plant G9 (8.10.8.6.1), which based on previous analyses should have transgene $1.1 \mathrm{~kb}$, was in fact a resistant plant but produce progenies that were mostly resistant, the rest being recovery.

Table 1 shows that the transgene $5.8 \mathrm{~kb}$ did not result in resistant, recovery, or less susceptible phenotype. This plant exhibited susceptible phenotype. This suggestion was obtained by comparing the Southern data and the phenotypic data of T5 progenies of a T4 plant G9 (1.3.1.1). All of 9 T5 progenies of T4 plant G9 (1.3.1.1), upon inoculation with PStV, showed susceptible response, and the other 3 T5 progenies had transgene of $5.8 \mathrm{~kb}$. This suggested that the transgene $5.8 \mathrm{~kb}$ was nonfunctional.

Table 2 shows Southern data of T5 plants and phenotypic data of their progenitor T2 and $\mathrm{T} 3$ plants. Since T2 and T3 plants must at least contained transgenes detected in T5 population, we should be able to correlate number of integration site of transgene with phenotype in term of plant response to PStV inoculation. T2 and T3 plants (Table 2, No.614) were resistant or recovery plants and at least contained transgene 1.1 and $1.3 \mathrm{~kb}$. Therefore, co-existence of those two transgenes led toresistance or recovery response. Co-existence of transgenes of $1.1 \mathrm{~kb}, 1.3 \mathrm{~kb}$ and $5.8 \mathrm{~kb}$ (Table 2, No.15) and transgene $1.3 \mathrm{~kb}$ and $5.8 \mathrm{~kb}$ (Table 2, No.16) also resulted in resistance or recovery response. 
Table 1. Segregation of response of $\mathrm{T} 5$ progenies of $\mathrm{T} 4$ transgenic peanut plants containing coat protein gene of peanut stripe virus (PStV) to mechanical inoculation of PStV and results of Southern analysis of T5 plants. The test plants were inoculated with PStV of severe blots strain at least three times.

\begin{tabular}{|c|c|c|c|c|c|c|c|c|c|c|c|c|c|}
\hline \multirow{2}{*}{ No. } & \multirow{2}{*}{ Lines } & \multirow{2}{*}{$\begin{array}{l}\text { Number of } \\
\text { T5 plants } \\
\text { grown }\end{array}$} & \multicolumn{5}{|c|}{$\begin{array}{c}\text { Number of T5 plants showing response } \\
\text { with indicated scores *) }\end{array}$} & \multirow{2}{*}{$\begin{array}{c}\text { Number of T5 } \\
\text { plants subjected to } \\
\text { Southern analysis }\end{array}$} & \multicolumn{5}{|c|}{$\begin{array}{l}\text { Number of T5 plants showing bands } \\
\text { with indicated sizes }\end{array}$} \\
\hline & & & 0 & 1 & 2 & 3 & 4 & & No bands & $1.1 \mathrm{~kb}$ & $1.3 \mathrm{~kb}$ & $5.8 \mathrm{~kb}$ & $\begin{array}{r}1.3 \mathrm{~kb}+ \\
5.8 \mathrm{~kb} \\
\end{array}$ \\
\hline 1 & $\mathrm{G}(17.1 .8 .1)$ & 4 & 0 & 0 & 0 & 0 & 3 & 1 & 1 & 0 & 0 & 0 & 0 \\
\hline 2 & $\mathrm{G}(1.5 .2 .1)$ & 4 & 0 & 0 & 1 & 0 & 1 & 2 & 1 & 0 & 0 & 1 & 0 \\
\hline 3 & $\mathrm{G}(1.3 .1 .1)$ & 12 & 0 & 0 & 0 & 0 & 9 & 3 & 0 & 0 & 0 & 3 & 0 \\
\hline 4 & $\mathrm{G}(6.2 .4 .1)$ & 9 & 7 & 0 & 0 & 0 & 1 & 1 & 0 & 1 & 0 & 0 & 0 \\
\hline 5 & $\mathrm{G}(6.4 .3 .1)$ & 6 & 0 & 1 & 1 & 2 & 0 & 2 & 0 & 2 & 0 & 0 & 0 \\
\hline 6 & $\mathrm{G}(6.4 .14 .2)$ & 10 & 2 & 0 & 0 & 0 & 5 & 3 & 0 & 3 & 0 & 0 & 0 \\
\hline 7 & $G(8.10 .8 .4)$ & 6 & 5 & 0 & 0 & 0 & 0 & 1 & 0 & 1 & 0 & 0 & 0 \\
\hline 8 & $\mathrm{G}(8.10 .8 .6)$ & 10 & 8 & 0 & 0 & 0 & 0 & 2 & 0 & 2 & 0 & 0 & 0 \\
\hline 9 & $\mathrm{G}(6.1 .3 .1)$ & 6 & 3 & 0 & 1 & 0 & 0 & 2 & 0 & 1 & 1 & 0 & 0 \\
\hline 10 & $\mathrm{G}(6.4 .14 .1)$ & 6 & 1 & 0 & 0 & 0 & 2 & 3 & 0 & 2 & 1 & 0 & 0 \\
\hline 11 & $\mathrm{G}(8.4 .3 .1)$ & 4 & 1 & 0 & 0 & 0 & 0 & 3 & 0 & 1 & 2 & 0 & 0 \\
\hline 12 & $\mathrm{G}(8.15 .4 .1)$ & 9 & 1 & 2 & 1 & 2 & 0 & 3 & 0 & 2 & 1 & 0 & 0 \\
\hline 13 & $\mathrm{G}(8.17 .1 .1)$ & 10 & 4 & 2 & 0 & 1 & 0 & 3 & 0 & 2 & 1 & 0 & 0 \\
\hline 14 & $\mathrm{G}(9.2 .5 .1)$ & 8 & 3 & 2 & 0 & 0 & 0 & 3 & 0 & 2 & 1 & 0 & 0 \\
\hline 15 & $G(9.4 .16 .1)$ & 6 & 3 & 0 & 0 & 0 & 0 & 3 & 0 & 2 & 1 & 0 & 0 \\
\hline 16 & $\mathrm{G}(16.4 .19 .1)$ & 4 & 2 & 0 & 0 & 0 & 0 & 2 & 0 & 1 & 1 & 0 & 0 \\
\hline 17 & $\mathrm{G}(18.1 .5 .1)$ & 4 & 0 & 0 & 0 & 0 & 1 & 3 & 0 & 1 & 2 & 0 & 0 \\
\hline 18 & $\mathrm{G}(16.4 .1 .1)$ & 11 & 1 & 4 & 0 & 2 & 1 & 3 & 0 & 1 & 1 & 0 & 1 \\
\hline 19 & $G(8.11 .6 .1)$ & 6 & 2 & 0 & 1 & 1 & 0 & 2 & 0 & 0 & 2 & 0 & 0 \\
\hline 20 & $\mathrm{G}(8.14 .4 .1)$ & 7 & 2 & 2 & 1 & 0 & 0 & 2 & 0 & 0 & 2 & 0 & 0 \\
\hline 21 & $\mathrm{G}(18.2 .2 .1)$ & 5 & 2 & 2 & 0 & 0 & 0 & 1 & 0 & 0 & 1 & 0 & 0 \\
\hline 22 & $\mathrm{G}(16.4 .15 .1)$ & 9 & 1 & 0 & 0 & 4 & 3 & 1 & 0 & 0 & 0 & 0 & 1 \\
\hline
\end{tabular}

*) As described at Figure 1 
*) as described at Figure 1 
Southern analysis showed most of T5 plants contained either transgene $1.1 \mathrm{~kb}, 1.3 \mathrm{~kb}$, or $5.8 \mathrm{~kb}$, suggesting that those three transgene were located at separate loci, or even at different chromosome that render independent assortment. Eventhough there were two T5 plants (progenies of G9 (16.4.1.1) and G9(16.4.15.1) that contained both transgene $1,3 \mathrm{~kb}$ and $5,8 \mathrm{~kb}$, these transgenes segregated.

In genetic engineering, prove that transgene is integrated in genom is not the only goal. The other goal is that the transgene should be functional. In this research, we obtained resistant and recovery plants with regards to their response to PStV inoculation. This indicates that the transgenes was functional. The T0 plants contained at least transgene $1.1 \mathrm{~kb}, 1.3 \mathrm{~kb}$ and $5.8 \mathrm{~kb}$ and we need to know which one is functional and which one is not.

To find out whether or not a transgene is functional could be carried out by Southern analysis and by looking phenotype of the same plants. Unfortunately, we did not inoculate T5 plants that were subjected to Southern analysis and we did not conduct Southern analysis of the plants that were PStV-inoculated. Therefore, we could not get direct proofs that a particular transgene cause a particular phenotype. The available data is penotypic data of some T5 progenies of a T4 plant and Southern data of the other T5 progenies of the same T4 plant. By comparing both data, we could predict correlation between the existence of a transgene and the phenotype.

Based on the comparison between Sourthern data and phenotypic data we predict that the transgene $1.1 \mathrm{~kb}$ and $1.3 \mathrm{~kb}$ might result in resistant or recovery plants and the transgene $5.8 \mathrm{~kb}$ was not functional, meaning that it did not cause resistant, recovery, and less susceptible response so the plants containing trasngene $5.8 \mathrm{~kb}$ showed a symptom of severe blotch on their leaves. The existence of functional and nonfunctional transgenes might be due to positional effects, a phenomenon in which the insertion positions of a transgene in a genom of a transgenic plant influence its transcription. A transgene that inserted in heterochromatin region has been reported to undergo transcriptional inhibition while that inserted in euchromatin regions did not undergo transcriptional inhibition.

Resistance of transgenic plants containing viral genes against the corresponding viruses has been found to be through post-transcriptional gene silencing (PTGS). PTGS required that the transgene was transcribed (Vaucheret et al., 1997). Therefore, a transgene positioned in regions that render it untranscriptable would not result in PTGS. In this research the transgene $5.8 \mathrm{~kb}$ might not result in PTGS so it was not functional. The trannsgene $1.1 \mathrm{~kb}$ and $1.3 \mathrm{~kb}$, on the other hand, might result in PTGS so it was functional and result in resistance and recovery phenotype.

Either transgene $1.1 \mathrm{~kb}$ or transgene $1.3 \mathrm{~kb}$ led to resistance or recovery phenotype. This was based upon the finding that a resistant transgenic T5 plant produced $\mathrm{T} 6$ progenies comprised of mostly resistant plants and the rest were recovery plants. This was also based on the finding that a recovery $\mathrm{T} 5$ plant produced T6 progenies that were all resistant to PStV. Research on transgenic tobacco plants containing $\mathrm{cp}$ gene of TEV (tobacco etch virus) showed that a resistant transgenic tobacco plant produced progenies that showed recovery symptom eventhough the transgene was stably integrated. This phenomenon referred to as meiotic resetting (Depicker et al., 1997; Stam et al., 1997; Matzke and Matzke, 1998), that is, each generation of transgenic plants needs reinitiation of PTGS. In other words, it takes some time for progenies of a virus-resistant transgenic plants before they show resistance mediated by PTGS. Therefore, whether the plant response is resistance or recovery depends on when the inoculation is conducted. When the inoculation is done at the early stage of plant development, the response is recovery. On the other hand, when the inoculation is done at the later stage of plant development, the response is resistance. Based on the phenomenon of meiotic resetting, Butterfield et al., (2002) recommended that inoculation of sorghum mosaic virus (SrMV) to transgenic sorghum was conducted at later stage of plant development, not at the early stage (seedling stage).

In this research, a phenomenon of gene dosage did not seem to occur. One and more integration sites of functional transgene resulted in the same phenotype. A phenomenon of gene dosage did occur in transgenic tobacco containing coat protein gene of tobacco etch virus (TEV) as reported by Goodwin et al.(1996). They reported that transgenic tobacco plants containing two or more integration sites of TEV coat protein gene were resistant to TEV, while those containing one integration site exhibited recovery response to TEV inoculation. 


\section{CONCLUSIONS}

Transgenic peanut plants containing PStV coat protein gene has been produced. Three intergration sites of transgene were detected using Southern analysis. Either transgene $1.1 \mathrm{~kb}$ or $1.3 \mathrm{~kb}$ resulted in resistance or recovery response, while transgene 5.8 $\mathrm{kb}$ was not functional. The resistance mechanism might be through post-transcriptional gene silencing (PTGS). Further investigation is needed to prove that the mechanism was indeed a PTGS. It could be carried out by employing a nuclear-run on analysis of transgenic peanut plants containing transgene $1.1 \mathrm{~kb}$ or $1.3 \mathrm{~kb}$ and $5.8 \mathrm{~kb}$.

\section{ACKNOWLEDGEMENT}

We thank the Directorate General of Higher Education, the Department of National Education of Indonesia for funding this research and Queensland Agricultural Biotechnology Centre for providing facilities to do Southern analysis.

\section{LITERATURES CITED}

Akin, H.M. 1998. Peanut Stripe Virus Strain Indonesia: Variasi Biologi, Deteksi Molekuler, Pengklonan, dan Determinasi Urutan Nukleotida 3'Genom RNA PStV, serta Analisis Keragaman dan Filogenetika Berdasarkan Gen CP dan 3'UTR. Disertasi. Program Pascasarjana Institut Pertanian Bogor.

Avivi S., 2000. Berbagai Tipe Konstruksi Gen cp PStV yang Dapat Memproteksi Tanaman Nicotiana benthamiana Transgenik terhadap Infeksi PStV pada Kacang Tanah. Disertasi. Program Pascasarjana Institut Pertanian Bogor.

Baulcombe, D.C. 1996. RNA as a target and an initiator of post-transcriptionally gene silencing in transgenic plants. Plant Mol.Biol. 32:79-88.

Butterfield, M.K., J.E. Irvine, M.V.Garza, \& T.E. Mirkov. 2002. Inheritance and segregation of virus and herbicide resistance transgenes in sugarcane. Theor Appl Genet 104: 797-803.
Depicker, A. \& M.van Montagu. 1997. Posttranscriptional gene silencing in plants. Curr.Opin. Cell. Biol. 9: 373-382.

English, J.J., E.Mueller, \& D.C. Baulcombe. 1996. Suppression of virus accumulation in transgenic plants exhibiting silencing of nuclear genes. The Plant Cell 8:179-188.

Fagard, M. \& H.Vaucheret. 2000. (Trans)Gene Silencing in Plants. Annu.Rev.Plant Physiol.Plant Mol.Biol.51:167-194.

Goodwin, J., K.Chapman, S. Swaney, T.Dawn, T.D. Parks, E.A. Wernsman, \& W.G. Dougherty. 1996. Genetic and biochemical dissection of transgenic RNA-mediated virus resistance. The Plant Cell 8: 95-105.

Hapsoro, D., J.Harjosudarmo, H.Aswidinnoor, R. Suseno, \& Sudarsono. 2005. Transformasi tanaman kacang tanah (Arachis hypogaea L.) dengan gen cp PStV dengan bantuan Agrobacterium. Jurnal Agrotropika 10(2): 85 93.

Hapsoro, D. 2005. Resistensi Kacang Tanah (Arachis hypogaea L.) Transgenik terhadap PStV: Identitas, Jumlah Integrasi, Ekspresi, dan Stabilitas Transgen cp PStV. Disertasi. Sekolah Pascasarjana Institut Pertanian Bogor.

Higgins, C.M. \& G.R. Dietzgen. 2000. Genetic transformation, regeneration, and analysis of transgenic peanut. ACIAR Technical Reports Series 48

Matzke, A.J.M. \& M.A. Matzke. 1998. Position effects and epigenetic silencing of plant transgenes. Curr.Opin.Plant Biol.1: 142-148.

Matzke, M.A. \& A.J.M. Matzke. 1995a. How and why do plants inactivate homologous (trans)genes? Plant Physiol.107:679-685.

Matzke, M.A. \& A.J.M. Matzke. 1995b. Homologydependent gene silencing in transgenic plants: what does it really tell us? Trends in Genetics 11(1): 1-3. 
Meyer, P. 1995. Understanding and controlling transgene expression. Trends in Biotechnology 13: 332-337.

Meyer, P. \& H.Saedler. 1996. Homology-dependent gene silencing in plants. Ann.Rev.Plant Physiol.Mol.Biol. 47:23-48.

Mlotshwa, S., O.Voinnet, M.F.Mette, M.Matzke, H.Vaucheret, S.W.Ding, G. Pruss, \& V.B. Vance. 2002. RNA silencing and the mobile silencing signal. The Plant Cell: S289-S301.

Mueller, E., J.E. Gilbert, G. Davenport, G. Brigneti, \& D.C. Baulcombe. 1995. Homology-dependent resistance: transgenic virus resistance in plants related to homology-dependent gene silencing. Plant J. 7: 1007-1011.

Murray, M.G. \& W.F. Thompson. 1980. Rapid isolation of high molecular weight plat DNA. Nucl.Acids Res. 8:43214325.

Prins, M., R. de Oliveira Resende R, C. Anker, A. van Schepen, P. de Haan, \& R. Goldbach. 1996. Engineered RNA -mediated resistance to tomato spotted wilt virus is sequence specific. Mol.Plant-Microbe Interact. 9: 416-418.
Smith, H.A., S.I. Swaney, T.D. Parks, E.A. Wernsman, \& W.G. Dougherty. 1994. Transgenic plant virus resistance mediated by untranslatable sense RNAs: expression, regulation, and fate of nonessential RNAs. The Plant Cell 6: 1441-1453.

Stam, M., J. Mol, \& J. Kooter. 1997. The silence of genes in transgenic plants. Ann Bot. 79:3-12.

Vance, V. \& H. Vaucheret. 2001. RNA silencing in plants: defense and counterdefense. Science 292: 2277-2280.

Vaucheret, H, L. Nussaume, J.C. Palauqui, I. Quillere, \& T. Elmayan. 1997. A transcriptionally active state is required for post-transcriptional silencing (cosuppression) of nitrate reductase host genes and transgenes. The Plant Cell 9: 1495-1504.

Yasin, N. 2001. Evaluasi ketahanan tanaman transgenik model Nicotiana benthamiana terhadap peanut stripe virus. Tesis. Program Pascasarjana Institut Pertanian Bogor. 